ROCZNIKI TEOLOGICZNE

Volume LXV, issue $10-2018$

Englis h version

DOI: http://dx.doi.org/10.18290/rt.2018.65.10-6en

REV. WITOLD JANOCHA

\title{
THE PROCESS OF A FAMILY ADAPTING TO A CHILD'S DISABILITY
}

\begin{abstract}
A preliminary analysis of the conducted research indicates that the psychosocial situation of a family who has a member with a disability is very difficult and complex. Answers to important and interesting questions asked during the course of empirical research where given by parents and people with disabilities. They presented the image of a family seeking to understand their situation and trying to cope with all kinds of problems. These include such things as finances or professional activity, striving to adapt to the new situation and being strongly committed to looking after a disabled person. Unfortunately, as the research results indicate, caretaking activity is the domain of one person in the family, meaning the mother.
\end{abstract}

Keywords: disability; family; adaptation.

The issue of a disability is a frequently studied topic within many scientific disciplines. Researchers are trying to approximate the psychosocial situation of people with disabilities by exploring their system of values, sense in life, and their participation in the educational system or the labor market. The family that participates in their child's disability to a large extent bears the challenging consequences of the disability.

According to the family system, a disability is not the individual's problem, but through a network of relationships, it is a situation in which the closest environment is involved. As Z. Kawczyńska-Butrym points out, the problem of a disability affects the entire family and its functioning in all its dimensions. ${ }^{1}$

Rev. Dr. Hab. Witold JANOCHA, KUL Professor at the Department of Social Integration for Persons with Disabilities, Institute of Family Studies and Social Work, John Paul II Catholic University of Lublin; mailing address: Al. Racławickie 14, 20-950 Lublin, e-mail: wjanocha@kul.pl

${ }^{1}$ Zofia KAWCZYŃSKA-BUTRYM, Wyzwania rodziny: zdrowie, choroba, niepetnosprawność, starość (Lublin: Wydawnictwo Makmed, 2008), 138. 
The consequences most frequently discussed in the literature include one's existential sphere, which is connected with the deterioration of a family's economic and existential situation, resulting from large financial costs spent on treatment, rehabilitation, private visits to specialists, home accommodation adjustments, and purchasing orthopedic equipment. It is not an easy situation, and in many cases things get worse when the decision is made, most often by mothers, to suspend their professional activity for childcare, which significantly weakens the financial condition of a family. This situation causes a drop in lifestyle, limiting consumption and contributing to the social marginalization of the family. ${ }^{2}$

Another area in which the family is severely affected by the child's disability is the emotional sphere, which concerns the experiences of parents and the environment after the birth of the child with a disability. Parents experience enormous stress, and they are overwhelmed by fear of the future for the child and the entire family. Their emotional state is expressed in this opinion: the end of our dreams, the end of joy, no future for us, shock. ${ }^{3}$

In many cases, parents blame themselves for their child's disability, which reduces their self-esteem, deepens their stress, and all this leads to depression. A child's disability is also an insistent search for answers to such questions as: "Why did this happen to me?" "What is the meaning of my child's disability?" "What is the meaning of life?" "Is our disabled child's life as equally valuable as those of non-disabled people?"4

To a great extent, the child's disability affects family relationships as well as their environment. The current state of research indicates that the

\footnotetext{
${ }^{2}$ Witold JANOCHA, Poczucie sensu życia osób z niepetnosprawnościa (Kielce: Wydawnictwo Jedność, 2008), 36. Cf. Janusz KiRENKO, "Osoba z dysfunkcją narządu ruchu z powodu uszkodzeń rdzenia kręgowego," in Osoby niepetnosprawne w środowisku lokalnym. Wyrównywanie szans, ed. Barbara Szczepankowska, Jerzy Mikulski (Warszawa: Centrum Badawczo-Rozwojowe Rehabilitacji Osób Niepełnosprawnych, 1999), 86-93; Janusz KIRENKO, "Wsparcie społeczne rodzin z dzieckiem niepełnosprawnym i jego uwarunkowania," in Rodzina źródtem życia i szkoła miłości, ed. Dorota Kornas-Biela (Lublin: TN KUL, 2000), 385-392; Dorota GŁoGosz, Bożena KoŁACZEK, "Sytuacja wewnątrzrodzinna i warunki rozwojowe dzieci," in Rodzina wielodzietna w Polsce. Teraźniejszość i przyszłość, ed. Bożena Balcerzek-Paradowska (Warszawa: Instytut Pracy i Spraw Socjalnych, 1997), 72-87.

${ }^{3}$ KAWCZYŃSKA-Butrym, Wyzwania rodziny, 133. Cf. Maria CHOdKowsKa, "Kulturowe uwarunkowania postaw wobec inwalidztwa oraz osób niepełnosprawnych. Ciągłość i możliwość zmian," in Człowiek niepetnosprawny. Problemy autorealizacji i spotecznego funkcjonowania, ed. Maria Chodkowska (Lublin: Wydawnictwo UMCS, 1994), 159-184.

${ }^{4}$ Janocha, Poczucie sensu życia osób z niepetnosprawnościa, 37. Cf. Ewa Pisula, Jarosław RolA, "Radzenie sobie ze stresem przez rodziców dzieci o zaburzonym rozwoju," Roczniki Pedagogiki Specjalnej no 5 (1994): 161-172.
} 
main burden of caring for a disabled child falls on the mother. Fathers tend to find some activity away from the home or, as many examples suggest, simply abandon the family by withdrawing from being a guardian. ${ }^{5}$ The mother takes on the role of the only caretaker, and this can lead to the socalled caregiver syndrome, where the mother comes to believe that nobody else can take good care of her child. Care and work absorb all her time and strength. ${ }^{6}$ Concentrating only on a disabled child may in turn lead to neglecting other family members, especially its siblings. There is loose control over the behavior of the other children, their achievements in learning, friendships and contacts, including limited time spent outside the home. ${ }^{7}$

Another important area of family life affected by the child's disability is their social and cultural life. In the event of a disability, former friends and acquaintances usually move aside, limiting or severing social contacts with the disabled person and his or her family. Also, parents themselves withdraw from their social life because the environment, often not understanding the behavior of a disabled child, perceives them stereotypically and reacts negatively to both the child and its parents. ${ }^{8}$ Such reactions cause parents to avoid social contacts, sometimes even with their closest family members. As parents declared, it is very stressful for them to take their disabled child to the movies or theater, because they cannot predict their child's behavior or how the surrounding people will react. Thus, parents avoid stressful situations, and this wins over participating in their cultural and social life. ${ }^{9}$ Restrictions in how the family functions as a result of a disability constitute a real threat to being marginalized or even excluded from one's social life. The family is not able to get out of their crisis on its own, and helpful institutions and organizations have an important role to play in these cases.

\footnotetext{
${ }^{5}$ Monika PARCHOMIUK, Rodzice dzieci z mózgowym porażeniem dziecięcym wobec sytuacji trudnych (Lublin: Wydawnictwo UMCS, 2007), 34.

${ }^{6}$ Ibidem, 30-31.

${ }^{7}$ Bożena SiDOR, "Trudności przeżywane przez rodzinę dziecka z niepełnosprawnością umysłową," in Rodzina: źródto życia i szkoła mitości, 395-398. Cf. Andrzej TwARDowsKi, Sytuacja rodzin dzieci niepetnosprawnych, in Irena ОВUCHOWSKA, Dziecko niepetnosprawne $w$ rodzinie (Warszawa: WSiP, 1999), 18-52.

${ }^{8}$ Antonina OstrowsKa, Niepetnosprawni w spoteczeństwie. Postawy spoteczeństwa polskiego wobec ludzi niepetnosprawnych (Raport z badań) (Warszawa: IFiS, 1994), 42-44.

${ }^{9}$ Jennifer B. Mactavish, "Family Caregivers of Individuals with Intellectual Disability: Perspectives on Life Quality and the Role of Vacation." Journal of Leisure Research Review 39 (2007): 127-155.
} 


\section{THE FAMILY ADAPTING TO A CHILD’S DISABILITY}

Adaptation, according to A. Schneiders, is the way in which "man deals with himself and others." More precisely, it is "a process involving both psychological (internal) and behavioral reactions, through which the individual effectively copes with internal needs, tensions, frustrations and conflicts in order to achieve a certain level of balance between their internal needs and the requirements imposed on the individual by the objective world in which he lives." 10 The adaptation process, however, cannot simply be explained by psychological factors, since it is a more complex process requiring a dynamic balance between an individual's internal requirements and the requirements of the social environment.

Accepting the state of a person's disability plays an important role in the adaptation process. A family who has low self-esteem due to their child's disability often avoids identifying with the environment and tries to keep the fact of a disability personal. If it is actually impossible to hide the disability, then the family, as long as it places itself lower than others, tries to act as if this deviation from the norm has no significance in its life. However, even if such a family manages to conceal the fact that their child is not quite capable, it cannot by its own conviction consider itself to be a fully worthy family, because simply admitting to be different is a necessary condition for accepting the existing differences. ${ }^{11}$

The author's research from quality tests on parents and people with disabilities discusses people's first reactions to a disability. ${ }^{12}$ Parents and people with disabilities described their reactions in a dramatic way.

Their first impression is shock, disbelief, and soon afterward constant stress, asking themselves if they can cope with this situation. Later, a person begins to adapt to the new reality by seeking to find the best solution.

I was devastated, scared, and I was constantly asking myself: why did this happen to me? (Interview 1. The mother of a girl born with a disability).

It was crazy, as if the earth opened up under my feet. I do not like to go back to that memory. We knew so little about this disease. I did not know that we could live with it (Interview 13. A mother of a disabled girl).

\footnotetext{
${ }^{10}$ Janusz KIRENKO, Oblicza niepetnosprawności (Lublin: WSS-P, 2006), 38-39.

${ }^{11}$ Ibidem, 37-48.

${ }^{12}$ Own research based on 85 in-depth interviews with handicapped people and their caretakers from the Holy Cross region.
} 
I was scared. I was also afraid that I would not be able to deal with this. Besides, my lack of knowledge made me even more annoyed. We did not know what was wrong with the child, because it was so small from the very beginning. Well, that's all I can say (Interview 15. A girl's mother born with a disability).

In a slightly different situation, there are people who have become disabled as a result of an accident or other random event. Such a reaction is presented in a very interesting way by a man who was interviewed:

I jumped into the water, broke my spine, and this paralyzed me. My uncle and dad were the ones who came and told me what was wrong and that a long rehabilitation period awaits me, but nobody told me that I would never walk again. I lay in the hospital, unconscious, and I slept all the time. At some point I woke up for a moment and a thought came to mind, and immediately I received an answer: "it was God's will." Then there was my reaction: "Well if this is so, then everything is fine" and again I fell unconscious.

Now I more often think about my disability, because I am paralyzed physically and mentally. I may be suffering from depression because I am also mentally inactive. There is no strength in me, no will power to do anything. I had a strong attack of depression, and I even wanted to commit suicide and even made a failed attempt to kill myself. But I heard my dad say that I was keeping pretty strong, because others have such a crisis after 3 or 4 years.

One day I got a book soon after my suicide attempt entitled "Jesus lives." It was about healing in the Holy Spirit renewal movement. At that moment, God entered into my consciousness, because until then I had not thought about God. I felt happy. After reading the book, I went to a meeting hoping to be healed, but in my depression, I was afraid that if I did not get healed, I would lose my faith completely. My expectations lowered the closer we got to Czestochowa. I met a group of young people who prayed over me and felt a warm and pleasant feeling. After returning, I entered the Church, it was my brother's First Communion, and after this event, my depression symptoms disappeared. I had a wave of euphoria and I began to read a lot about the Holy Spirit renewal. That's how things were going for me. But now it gets to me when I look at beautiful young women. I know that I do not function as a man should. I would like to live a better life, but I do not know how this could possibly happen (Interview 17. A man with an acquired disability).

In the next question in the interview, we attempted to obtain information about the interpretation of the difficulty of experiencing a disability. Here there are also answers full of emotions expressing misunderstanding and pain.

This situation cannot be explained. I thought I was the one who did something wrong: "what did I do wrong?" (Interview 13. A mother of a girl born with a disability).

I could not explain it, I was furious that I had to carry another cross, I was really angry (Interview 15. The mother of a girl born with a disability).

I do not know if it had to be like this, maybe it was just a coincidence, different things that happened and developed into a disease ... because I have diabetes ... 
and so I even asked why my parents got married in the first place since they knew that they had diabetes, and on the one hand, my grandmother also got sick, so why did they ever get married? This disease most often manifests itself in every second generation, so why did they ever get married, and why was I ever born, I am full of bitterness (Interview 20. A woman with an acquired disability).

It depends on the day. Sometimes it's just that I cannot completely explain what's happening. I simply do not have to, because it's the reality that I have found myself in, so I have absolutely no need to explain how to interpret this state. There were also such moments when I was angry at, I don't know .... God, my parents, everyone around me, because I am different (Interview 32. A woman born with a disability).

First of all, I have to explain that this situation was my mistake, and I must bear the consequences for it, but I consider, I also see God's plan for me in this situation, and I trust that the state in which I find myself has some meaning (Interview 30. A man with an acquired disability).

If arguments and traumatic experiences related with a disability are rather common, their interpretation and an attempt to explain the situation of a disability are not quite clear-cut. There are people who are lead by rebellion and "furiousness," but more and more often, after reflecting on these things, the thought comes that a disability may be associated with some deeper meaning, with God's plan.

In other studies conducted by the author, ${ }^{13}$ the respondents were asked the question: "To what extent are parents reconciled with the fact of their child having a disability." There is also no single answer to this issue. Just over one-third $(33.3 \%)$ of respondents stated that the fact of their child's incomplete efficiency was calmly accepted, and they treated it as a task to be undertaken and completed as best as possible. Slightly fewer respondents treat this problem as a destiny, or bad luck, "it must be so" and "we cannot leave family members unattended" (28.9\%). To a lesser extent, $22.9 \%$ of respondents deal with this problem in religious terms, as God's will, a cross that should be carried. $1.7 \%$ of respondents blame other people for the disability in the family, and $7.4 \%$ say that they have not yet come to terms with this fact and cannot explain why.

Statistically significant dependencies occurred between the discussed variable and the role played in the family (as a father, mother, or the disabled person). Persons with disabilities much more often (41.9\%) than

${ }^{13}$ Research carried out on a group of 720 families in the Holy Cross region. Cf. Witold JANOCHA, Religijność osób niepetnosprawnych i ich rodzin (Lublin: Wydawnictwo KUL, 2011); Witold JANOCHA, Rodzina z osobq niepetnosprawna w spotecznym systemie wsparcia (Kielce: $\mathrm{Wy}-$ dawnictwo Jedność, 2009). 
fathers $(32.7 \%)$ and definitely more often than mothers $(26.6 \%)$ declared that they passively accepted a disability and treated it as an assignment to take on. It can be concluded that it is actually much more difficult for parents to reconcile with the fact of their child's disability than for the disabled person. Understanding disability as blind fate, a predestination, which we cannot influence was most often stated by mothers $(34.0 \%)$ than fathers $(28.6 \%)$ and people with disabilities $(20.4 \%)$. Slightly more mothers $(8.0 \%)$ than fathers $(7.7 \%)$ and disabled people $(6.6 \%)$ were disappointed with the disability.

For many people, the situation of a child's disability involves the necessity to change one's hierarchy of values, causing a reorganization of one's time, the division of duties, and often leaving behind one's career. It is often also connected with considerably adapting the entire environment in which a disabled person will move. Hence, the important issue is to what extent the entire family has adapted to living with a disabled person and whether this required great sacrifices and expenses, or was it all a smooth transition to the new challenges posed from adapting themselves and the environment to functioning with a disabled person.

Just like in the previous issue, $33.3 \%$ of respondents stated that it was very easy to adapt to living with a disabled person and, basically, nothing had to be changed; the response it is easy, although it was necessary to adapt the house, was mentioned by $18.2 \%$ of respondents. It follows that over half of the families did not have major problems with adapting to life with a disabled person. It is important information that the child's disability did not become a cause of marginalization or social exclusion for them. Slightly less $(40.0 \%)$ of respondents declare that it was difficult for them to adapt to living with a disabled person. The reason for these problems was the necessity to settle many matters related to the necessity to continuously care take and undergo treatments, as well as the need to learn many new activities and tasks so that the disabled person could function rather normally. $2.9 \%$ of the surveyed families are still in the stage of continuously adaptating to the disability.

The confirmation of this statistical data are the statements of family members about coping with difficult situations taken from our conducted interviews:

It was all a very difficult situation for us, and although both of us worked, it was difficult for us to meet ends. There were long-term visits to doctors, specialists, and new medications, and we also had two daughters to care for (mother of a 17year-old girl with a moderate disability). 
It was very hard at the beginning, we had five children and only my husband worked. All our money was spent on treatments for our daughter and private visits to specialists. We borrowed money from family members and friends, but we always paid them back. Thanks to this, our daughter regained her hearing and was cured of epilepsy (the mother of a 27-year-old girl with a significant disability).

My husband and I somehow managed, he was working, I took care of the children, our parents kind of helped us. We spent our money carefully and had everything we needed, although it was not easy (a mother of a 27 -year-old child with a moderate disability).

Returning to our statistical analyses, we can see that it is easier for people with disabilities to adapt to a disability (35.6\%) than their parents (fathers$34.0 \%$, mothers $-30.0 \%$ ). Statistically significant dependencies occurred in the "easy" category, where the difference between disabled people and mothers came out to seven percentage points. Adaptation to life with a disabled person is heavily influenced by the severity of a disability, which seems to be obvious. A child who is seriously disabled requires parents to make more sacrifices and introduces many changes, not only in the home's furnishings, but also in their hierarchy of values. This is indicated by the statistically significant differences that we can observe in this variable. When combining the "very easy" and "easy" categories, we can include more families where there is a person with a light disability (61.3\%) than with a significant disability (44.8\%). Families with light disabilities declared that they had no major problems with adapting to life in the new situation. In the "very difficult" and "difficult" categories, problems with adapting were much more often indicated by the parents of a child with a significant disability $(47.6 \%)$ than a light disability (26.6\%).

\section{TAKING CARE OF A DISABLED PERSON}

Another issue discussed in the research concerned the burden that a family has to undertake when caring for a disabled person. These burdens have multiple characteristics. T. Tomaszewski writes about both financial problems and negative social attitudes, deprivations, meaning, their inability to satisfy their child's or their own needs due to excessive duties at home as well as the mental burdens caused by family conflicts. ${ }^{14}$

The conducted research indicates that for $89.6 \%$ of the respondents, a disability causes increased financial expenses, which contributes to worsening a family's

\footnotetext{
${ }^{14}$ Tadeusz Tomaszewski, "Człowiek i otoczenie," in Psychologia, ed. Tadeusz Tomaszewski, (Warszawa: PWN, 1975), 13-36.
} 
financial situation. A high percentage (72.6\%) gave us a theorem: a disability requires sacrifice and leads to the inability to satisfy personal needs. $67.5 \%$ of respondents admitted that a child's disability is the cause of many family conflicts. They claimed that they had to find a way to deal with difficult and conflicting family situations. A high percentage of respondents (65.6\%) mentioned that there was a physical burden taken on for life associated with the need to take care of a disabled person, which leads to the deterioration of one's health.

$59.3 \%$ of respondents declared that caring for a disabled person requires abandoning their job, and around $40-48 \%$ of the respondents indicated that their child's disability contributes to neglecting other family members, leading to limited control over progress in learning or their other children meeting peers. Similarly, it was pointed out that many had to resign from going to the cinema, theater, concerts, etc. $36.8 \%$ of respondents declared they had to resign from going on vacation, summer camps and visits to relatives. The least percentage (29.3\%) stated that their child's disability contributed to their abandoning pilgrimages and religious meetings.

A more descriptive presentation of these family situations are the comments of family members based on our conducted interviews:

We have already given up everything that we had. We saved on everything, even on food, and often my husband and I eat anything. The most important thing is for our son to have what he likes to eat. My son often invents some dishes, sometimes even a few a day, I have to prepare them, because if not, he does not want to eat at all. I used to go out with my husband, we liked company and dancing, but we had to give up everything. I do not even remember the last time we were simply together. This is due to financial reasons, but also because people have turned their backs on us, we no longer have friends or even acquaintances whom we can go visit.

We have never been on vacation in our lives and this is basically due to financial reasons. Once, when we lived by the sea, I explained to myself that at any moment I could go to the beach and simply rest, and I do not need to go anywhere to relax. But I would really like to go somewhere with my son. Mieszko also likes traveling very much, although he rarely leaves home. We are now saving money, so that after his confirmation he will go with the priest and other children to Czestochowa (Interview 47 . The mother of a 16 -year-old boy with a significant disability).

It was also a difficult period when our son was growing up, because my husband could not stand it and simply left us, he moved away to his daughter. Fortunately, he understood everything and came back to us, and now he is my only support, I would not be able to do anything without him. I have changed a lot because of this situation, I learned humility. Before I was open, courageous, rebellious, and now I can subordinate to others and have calmed down, I pray more, but I was not 
like that earlier (Interview 54. A mother of a 16-year-old boy with a significant disability).

I had to give up my job completely so that I could devote my time to raising my daughter. There was no other option, because my daughter doesn't tolerate being without me, and besides, I do not have someone to stay with her when I go to work. My daughter has lessons in school, but unfortunately, the school is far away, so I have to travel to school over $30 \mathrm{~km}$ every day, where she is given proper care and therapy (Interview 78. Mother of an 8-year-old girl with a light degree of disability).

The above statements are reflected in the statistical data from which it follows that mothers declared more often the need to leave work due to caring for a disabled child $(65.6 \%)$ than fathers $(55.9 \%)$. The same applies to the claim that there is a need to change jobs and suspend one's professional activity. In this case, mothers declared more frequently the need to make such a change $(56.3 \%)$ than fathers $(48.1 \%)$. A statistically significant dependence occurred in the variable "dealing with conflicts in the family." This problem was more frequently indicated by $69.6 \%$ of mothers rather than $60.4 \%$ of fathers, as well as their limited control over the birth of a disabled child (52.0\% of mothers, $44.0 \%$ of fathers) and restrictions on the possibility of making pilgrimage trips and attending religious meetings $33.3 \%$ of mothers, $22.2 \%$ of fathers).

\section{THE ENVIRONMENT PARTICIPATING IN CARING FOR A DISABLED PERSON}

As indicated above, a mother most often resigns from her professional work activity and/or restricts it by dedicating herself to her child. This usually leads to mental strain, breaking contacts with the wider environment, staying at home, and this consequently ends in burnout. ${ }^{15}$ In this context, the question about the division of roles in the family is interesting. Other family members engage in helping and caring for a disabled person by supporting the mother in her work.

In the description of the situation of families with a disabled child, we asked the following question: who spends the most time with the disabled person? Respondents were to mention three persons according to the amount of caretaking time. The obtained data show that mothers are the most com-

\footnotetext{
${ }^{15}$ JANOCHA, Poczucie sensu życia, 36-37.
} 
mitted people and burdened with these duties (93.0\% of respondents), fathers took second place $(65.0 \%)$, and siblings were third (sisters at $33.2 \%$, brothers at $25.1 \%$ ). Further family members participate, to a lesser extent, in caring for a disabled child $(23.5 \%)$, neighbors in a minimal way $(4.9 \%)$ and finally, social caretakers $(5.1 \%)$ or volunteers $(1.2 \%)$.

The above question is complemented by the issue of the division of duties in the family and the involvement of all in caring for the child. The following data show the people who do the caretaking.

Table 1. Responsibilities the following people have in caring for a disabled child (data in \%).

\begin{tabular}{|l|l|l|l|l|l|l|l|}
\hline Responsibilities to take on & Other & Father & Sister & Brother & $\begin{array}{l}\text { Further } \\
\text { family }\end{array}$ & Caretaker & Volunteers \\
\hline Preparing meals & 83.8 & 21.2 & 6.7 & 2.2 & 1.7 & 1.4 & 0.1 \\
\hline $\begin{array}{l}\text { Washing clothes and caring } \\
\text { to clean the person }\end{array}$ & 83.3 & 8.9 & 4.7 & 0.8 & 1.1 & 1.2 & 0.0 \\
\hline $\begin{array}{l}\text { Cleaning up and } \\
\text { maintaining the place } \\
\text { where the disabled person } \\
\text { lives }\end{array}$ & 78.1 & 14.4 & 10.4 & 4.2 & 1.1 & 2.2 & 0.1 \\
\hline $\begin{array}{l}\text { Doing grocery shopping } \\
\text { for the required diet }\end{array}$ & 74.7 & 30.7 & 8.3 & 5.6 & 2.9 & 1.2 & 0.6 \\
\hline $\begin{array}{l}\text { Contacting the doctor and } \\
\text { buying medications }\end{array}$ & 78.8 & 21.8 & 1.9 & 1.9 & 1.2 & 0.7 & 0.4 \\
\hline $\begin{array}{l}\text { Repairing and maintaining } \\
\text { orthopedic and } \\
\text { rehabilitation equipment }\end{array}$ & 24.3 & 25.0 & 1.7 & 2.9 & 1.7 & 0.6 & 0.3 \\
\hline $\begin{array}{l}\text { Taking care of all } \\
\text { administrative matters on } \\
\text { behalf of a disabled } \\
\text { person }\end{array}$ & 76.0 & 26.8 & 3.2 & 1.9 & 1.0 & 1.1 & 0.4 \\
\hline
\end{tabular}

Source: own research studies

The above data clearly presents that the mother has a great role in caring for a disabled child. They start with preparing meals (83.3\%), then clean the home and wash the disabled person $(83.3 \%)$, keep in touch with a doctor (78.8\%) and settle administrative matters (76.0\%). Then there is maintenance and repair of rehabilitation and orthopedic equipment (24.3\%), and it 
turns out that all these burdens are the mother's duties. There are several reasons for this situation: first, $21.4 \%$ of the surveyed families are single parent families with the mother as the head of the family, hence a high percentage of women in the mentioned daily life activities; the second reason is probably fathers who withdraw from the guardianship function over a disabled child.

Fathers often kind of "escape" by working outside the home. They focus on earning money and caring for the family's financial security, unwillingly engaging in caring for a disabled child; yet another reason for this may be the protective parenting mother type who, leaving behind her professional work, also gives up many other things entirely to care for their child. She is convinced that no one is able to complete her chores, and so no one else is able to cope with the tasks that the state of the child's disability bring about. It is interesting to note that respondents stated there was a very low percentage of social care helpers who supported their family. Their share in helping families in individual activities is just over $1 \%$. It should also be noted that there was practically zero volunteer participation in supporting a family with a disabled person.

Interviewers asked respondents to share their experiences of caring for a disabled family member. Here are some of their statements:

I think I can somehow handle this, at least I will try to do my best. Lucy is my child and I try to provide her with everything that we can afford. The most important thing is not to break down and fight, we cannot shut ourselves within these four walls and avoid contacts with others. If we know that something is wrong with our child, we must do something as soon as possible and inform a specialist about it. The most important thing is to go forward, not to break down (Interview 67. A mother of a girl born with a disability).

What is the worst kind of fatigue that we need to overcome? Mental fatigue is the worst, and even worse is the burnout syndrome, various kinds of depression, neurotic conditions and moments of fatigue, where physical fatigue also appears (Interview 79. A mother of a girl born with a disability).

Sometimes Marcin stays with my mother, but he is blind, he does not see, so I cannot go out for longer than an hour. But I'm happy that I can at least get this much help. In a crisis situation, our children will always help, but they have their own lives to live [...]. Physical fatigue is definitely the most difficult thing. The worst thing is taking Marcin to the bathtub. If I cannot handle it, I simply tell myself that I have to .... and then my strength returns (Interview 45. The mother of a boy with acquired disabilities). 
The process of a family adapting to a child's disability is complex and difficult. It is not only about psychological reactions and reconciling with the fact of a disability, but also adaptating the external environment by eliminating various kinds of barriers and limitations. It means properly managing home finances, which are often overwhelming due to the high costs of rehabilitation and the need to purchase various types of expensive equipment. Added to this is one of the parents resigning from their professional activity, most often the mother, which causes more economic hardships. In the entire process of adaptation, it is important to distribute household duties evenly among the family members, because, as research has shown, the mother first of all takes on excess tasks, which leads to her being fatigued, depressed and often marginalized.

\section{BIBLIOGRAPHY}

СноDкowska, Maria. "Kulturowe uwarunkowania postaw wobec inwalidztwa oraz osób niepełnosprawnych. Ciągłość i możliwość zmian.” In Człowiek niepetnosprawny. Problemy autorealizacji i spotecznego funkcjonowania [Cultural determinants of attitudes towards a disability and disabled people. Continual issues and possible changes, in: A disabled person. Problems with self-fulfillment and social functioning], edited by Maria Chodkowska, 159-184. Lublin: Wydawnictwo UMCS, 1994.

GŁoGosz, Dorota, Bożena KoŁACZEK. "Sytuacja wewnątrzrodzinna i warunki rozwojowe dzieci." In Rodzina wielodzietna w Polsce. Teraźniejszość i przyszłość [The family's internal situation and children's developmental conditions, in: Large families in Poland. The present and future], edited by Bożena Balcerzek-Paradowska, 72-87. Warszawa: Instytut Pracy i Spraw Socjalnych, 1997.

JANOCHA, Witold. Religijność osób niepetnosprawnych i ich rodzin [Religiosity among disabled people]. Lublin: Wydawnictwo KUL, 2011.

Janocha, Witold. Poczucie sensu życia osób z niepetnosprawnościa [The feeling of sense in the lives of people with disabilities]. Kielce: Wydawnictwo Jedność, 2008.

JANOCHA, Witold. Rodzina z osoba niepetnosprawna w spotecznym systemie wsparcia [A family with a disabled person in the social support system]. Kielce: Wydawnictwo Jedność, 2009.

KAWCZYŃSKA-BUTRYM, Zofia. Wyzwania rodziny: zdrowie, choroba, niepetnosprawność, starość [Family challenges: health, illness, disability, old age]. Lublin: Wydawnictwo Makmed, 2008.

KIRENKO, Janusz. Oblicza niepetnosprawności [The face of a disability]. Lublin: WSS-P, 2006.

KIRENKO, Janusz. "Osoba z dysfunkcją narządu ruchu z powodu uszkodzeń rdzenia kręgowego." In Osoba niepetnosprawna $w$ środowisku lokalnym. Wyrównywanie szans [A person with a motor dysfunction due to a damaged spinal cord, in: A disabled person in the local environ- 
ment. Equalizing opportunities], edited by Barbara Szczepankowska, Jerzy Mikulski, 86-93. Warszawa: Centrum Badawczo-Rozwojowe Rehabilitacji Osób Niepełnosprawnych, 1999.

KIRENKO, Janusz. "Wsparcie społeczne rodzin z dzieckiem niepełnosprawnym i jego uwarunkowania." In Rodzina źródtem życia i szkota miłości [Social support for families with disabled children and its determinants, in: The family is the source of life and the school of love], edited by Dorota Kornas-Biela, 385-392. Lublin: TN KUL, 2000.

MACTAVISH, Jennifer B. "Family Caregivers of Individuals with Intellectual Disability: Perspectives on Life Quality and the Role of Vacation." Journal of Leisure Research Review 39 (2007): 127-155.

Ostrowska, Antonina. Niepetnosprawni w społeczeństwie. Postawy społeczeństwa polskiego wobec ludzi niepetnosprawnych (Raport $z$ badan') [Disabled in society. The attitudes of Polish society towards people with disabilities (Research Report)]. Warszawa: IFiS, 1994.

PARChOMIUK, Monika. Rodzice dzieci z mózgowym porażeniem dziecięcym wobec sytuacji trudnych [Parents of children with cerebral palsy towards difficult situations]. Lublin: Wydawnictwo UMCS, 2007.

PIsula, Ewa, Jarosław Rola. "Radzenie sobie ze stresem przez rodziców dzieci o zaburzonym rozwoju" [Parents of children with impaired development coping with stress]. Roczniki Pedagogiki Specjalnej no 5 (1994): 161-172.

SIDOR, Bożena. "Trudności przeżywane przez rodzinę dziecka z niepełnosprawnością umysłową.” In Rodzina: źródto życia i szkota miłości [Difficulties experienced by the families of a child with a mental disability, in: Family: the source of life and school of love], edited by Dorota Kornas-Biela, 393-404. Lublin: TN KUL, 2000.

Tomaszewski, Tadeusz. "Człowiek i otoczenie." In Psychologia [Man and the Environment, in: Psychology], edited by Tadeusz Tomaszewski, 13-36. Warszawa: PWN, 1975.

TwARDOwSKI, Andrzej. "Sytuacja rodzin dzieci niepełnosprawnych." In Irena OBUCHOwsKA. Dziecko niepetnosprawne $w$ rodzinie [The situation of families with disabled children, in: Irena OвuchowsкA, A disabled child in the family], 18-52. Warszawa WSiP, 1999.

Translated by Jan Kobytecki

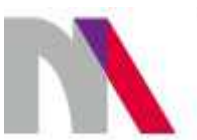

The preparation of the English version of Roczniki Teologiczne (Annals of Theology) and its publication in electronic databases was financed under contract no. 836/P-DUN/2018 from the resources of the Minister of Science and Higher Education for the popularization of science. 